\title{
Robust Multi-Objective Optimization of Solid Oxide Fuel Cell-Gas Turbine Hybrid Cycle and Uncertainty Analysis
}

\author{
Shivom Sharma ${ }^{1}$ \\ Industrial Process and Energy Systems Engineering \\ École Polytechnique Fédérale de Lausanne, EPFL, CH-1951 Sion, Switzerland \\ shivom.sharma@epfl.ch \\ François Maréchal \\ Industrial Process and Energy Systems Engineering \\ École Polytechnique Fédérale de Lausanne, EPFL, CH-1951 Sion, Switzerland \\ francois.marechal@epfl.ch
}

\section{ABSTRACT}

Chemical process optimization problems often have multiple and conflicting objectives, such as capital cost, operating cost, production cost, profit, energy consumptions and environmental impacts. In such cases, Multi-Objective Optimization (MOO) is suitable in finding many Pareto optimal solutions, to understand the quantitative trade-offs among the objectives, and also to obtain the optimal values of decision variables. Gas eous fuel ca n be converted into heat, power and el ectricity, using combustion engine, gas turbine (GT) or Solid Oxide Fuel Cell (SOFC). Of these, SOFC with GT has shown higher thermodynamic performance. This hybrid conversion system leads to a better utilization of natural resource, reduced environmental impacts, and more profit. This study optimizes performance of SOFC-GT system for maximization of annual profit and minimization of annualized capital cost, simultaneously. For optimal SOFC-GT designs, the composite curves for maximum amount of possible heat recovery indicate good performance of the hybrid system. Further, first law energy and exergy efficiencies of optimal SOFC-GT designs are significantly better compared to traditional conversion systems. In order to obtain flexible design in the presence of uncertain parameters, robust MOO of SOFC-GT system was also performed. Finally, Pareto solutions obtained via

\footnotetext{
${ }^{1}$ Corresponding author: shivom.sharma@epfl.ch
} 
normal and robust MOO approaches are considered for parametric uncertainty analysis with respect to market and operating conditions, and solution obtained via robust MOO found to be less sensitive.

\section{INTRODUCTION}

Industrial process and energy system optimization problems have several conflicting objectives related to economics, energy, environment and safety [1]. MultiObjective Optimization (MOO) is useful in finding many optimal solutions, to understand the quantitative trade-offs among the objectives, and also to obtain the optimal values of different decision variables. There are several conversion technologies that can convert gaseous fuels (e.g., $\mathrm{H}_{2}$ and $\mathrm{CH}_{4}$ ) into heat, power and electricity. Natural Gas (NG) can be used as fuel in internal combustion engines, Gas Turbines (GT) or Solid Oxide Fuel Cells (SOFC). SOFC with GT has high thermodynamic performance that leads to a better utilization of natural resource, improved sustainability, and more profit [2]. The unconverted fuel from the fuel cell stack is combusted in a catalytic burner, and then it is used in a GT to produce additional electricity. Bio-syngas and bio-gas have significant amount of $\mathrm{CO}_{2}$, and they can directly be used as fuel in the SOFC-GT system without $\mathrm{CO}_{2}$ separation. Hence, SOFC-GT system also helps in the separation of $\mathrm{CO}_{2}$, which can be stored/used for different applications.

Gasification converts biomass resource into bio-syngas, which has $\mathrm{CH}_{4}, \mathrm{H}_{2}$ and $\mathrm{CO}_{2}$ as main components. SOFC is a modern conversion technology, which has possibility of cogeneration, using different types of liquid and gaseous fuels. It can directly use biosyngas without the separation of $\mathrm{CO}_{2}$, or it can use bio-SNG (i.e., bio-syngas after $\mathrm{CO}_{2}$ separation). This study considers bio-gas as a fuel to the SOFC-GT system, which has 0.62 
mole fraction $\mathrm{CH}_{4}$ and remaining $\mathrm{CO}_{2}$. Conventionally, the unconverted part of the fuel $\left(\mathrm{H}_{2}, \mathrm{CH}_{4}\right)$ from the anodic side of SOFC is combusted to recover low temperature heat. Hence, several researchers have used other technologies along with SOFC, to achieve higher overall thermodynamic performance. Facchinetti et al. studied design and optimization of SOFC-GT hybrid cycle, and achieved exergy efficiency higher than $65 \%$ [2]. Recently, Ramadhani et al. reviewed many optimization studies on SOFC, and summarized common decision variables, objective functions, constraints and methods [3]. Marchetti et al. have performed real time optimization of SOFC stack [4]. Hajabdollahi and Fu optimized the configuration of SOFC-GT cogeneration plant using MOO approach [5]. Performance of an industrial process is highly influenced by the variabilities in the market and plant operation. Hence, effect of economics and plant conditions on the process design has been investigated in the literature $[6,7]$. Tock and Maréchal performed parametric uncertainty analysis of Pareto solutions obtained for $\mathrm{CO}_{2}$ capture in a power plant, and bio-SNG production from biomass resource [6], and suggested best optimal solutions for the implementation purpose.

This study optimizes design and operation of SOFC-GT system for annual profit and annualized capital cost, simultaneously. OSMOSE program, which has been used for the design and MOO of integrated energy system $[8,9]$, is used for the optimization. In the SOFC-GT optimization, several important operating parameters are chosen as decision variables. Further, Pareto optimal solutions are analyzed for heat integration, and for the first law energy and exergy efficiencies. Each Pareto solution represents an alternate SOFC-GT design, and selection of a design for the implementation purpose depends on 
the preference of the decision maker (values of objectives, company policy and environmental regulations) and sensitivity of the design with respect to uncertain operating and market parameters. The ultimate SOFC-GT design should be less sensitive (i.e., low variation in objective function) under uncertain economic scenarios. Hence, in this study, uncertainty analysis of obtained SOFC-GT system designs (i.e., Pareto solutions from normal MOO), with respect to yearly operation, plant life time, interest rate, fuel cell capital cost, electricity price, oxygen price and bio-gas price, is studied. The Pareto solutions are ranked based on the percentage to be the best Pareto solution and percentage to be in top 5 Pareto solutions, using 500 uncertain economic scenarios. This parametric uncertainty analysis is able to identify the least sensitive Pareto solution or SOFC-GT design.

Parametric uncertainty analysis of the Pareto solutions obtained via normal MOO approach may give only few less sensitive (or robust) solutions. The parametric uncertainties can be considered during $\mathrm{MOO}$, and it is referred as robust $\mathrm{MOO}$ [10]. For robust $\mathrm{MOO}$, process simulation has to be converged only once for a particular set of decision variables, but many values of each objective function are possible depending on the number of set of parameters values. Hence, each solution point in the decision variable space provides a cluster in the objective function space. Mean or median can be used to represent this cluster as a single point in the objective function space [10]. Note that, for each set of decision variables, one value of each objective function is required in MOO search. Sharma et al. applied robust MOO on hybrid plant for electricity production using wood [11], and found that robust MOO approach retains less sensitive solutions 
during the optimization. In this study, robust MOO of SOFC-GT system is performed to obtain flexible SOFC-GT design. Finally, Pareto solutions obtained from normal MOO and robust MOO approaches are compared, and robust MOO approach gives less sensitive solutions compared to normal MOO approach.

\section{SIMULATION OF SOFC-GT}

Fig. 1 presents a simplified schematic of SOFC-GT system, which is divided into five sub-systems: (1) fuel processing using steam reformer (SR), (2) SOFC, (3) cathodic GT (CGT), (4) anodic GT (AGT) and (5) $\mathrm{CO}_{2}$ compression. The SOFC-GT system has been simulated in BELSIM-Vali (version 4.7.0.3) flowsheeting software. As mentioned earlier, bio-gas is used as a fuel in SOFC-GT hybrid cycle which has 0.62 mole fraction $\mathrm{CH}_{4}$ and remaining $\mathrm{CO}_{2}$.

\section{INSERT Fig. 1}

In the fuel processing part, $\mathrm{CH}_{4}$ is partially converted into $\mathrm{H}_{2}$ inside a steam reformer. Both steam reforming reaction $\left(\mathrm{CH}_{4}+\mathrm{H}_{2} \mathrm{O}=\mathrm{CO}+3 \mathrm{H}_{2}, \Delta \mathrm{h}=206.11 \mathrm{~kJ} / \mathrm{mol}\right)$ and water gas shift reaction $\left(\mathrm{CO}+\mathrm{H}_{2} \mathrm{O}=\mathrm{CO}_{2}+\mathrm{H}_{2}, \Delta \mathrm{h}=-41.16 \mathrm{~kJ} / \mathrm{mol}\right)$ are performed inside the steam reformer. The partially reformed fuel enters the anodic side of a planar SOFC around $1000 \mathrm{~K}$, whereas hot air enters on the cathodic side. In this study, SOFC model developed by Van herle et al. is used, which also has possibility of internal reforming [12]. The SOFC model assumes anode supported cells, composite lanthanum strontium cobaltite ferrite cathode and metallic interconnectors. Further, the electrochemical 
model for SOFC considers diffusion losses at anode and cathode, and polarization and ohmic losses.

The temperature of air coming out from the catholic side of the SOFC is high, and so it can be used to produce electricity using cathodic turbine. The unused fuel from the anodic side of the SOFC is combusted in a catalytic burner in the presence of oxygen, and then it goes to anodic turbine to produce electricity. The outlet stream from the anodic turbine has mainly $\mathrm{CO}_{2}$ and water, and water is removed before the compression of $\mathrm{CO}_{2}$. $\mathrm{CO}_{2}$ is compressed to a very high pressure ( 125 bar) by a series of compressors and heat exchangers. Here, assumed values of isentropic efficiencies for turbines and compressors are 0.85 and 0.8 , respectively.

\section{MOO OF SOFC-GT}

Table 1 presents the formulated MOO problem for SOFC-GT system. In this optimization problem, maximization of annual profit and minimization of annualized capital cost are two objectives. The MOO problem has 10 decision variables, from all five sub-systems of SOFC-GT system. Ranges of all decision variables are decided based on the literature and preliminary analysis [2].

\section{INSERT Table 1}

The MOO of SOFC-GT system is performed using OSMOSE program (see Fig. 2), which has four key parts: (1) genetic algorithm (with clustering technique for maintaining the local optima) based MOO program: it provides values of decision variables, (2) simulation of SOFC-GT system in BELSIM Vali for new values of decision variables, (3) heat 
integration using values of temperatures and flow rates of important streams from SOFCGT simulation and (4) calculations of objective functions using SOFC-GT simulation data, heat integration results and/or fixed values of market and operating parameters.

\section{INSERT Fig. 2}

Annualized capital cost of SOFC-GT system is calculated using correlations and data given in Pelster [13], Maréchal et al. [14] and Turton et al. [15]; these correlations with data are given in the Supplementary Information. Further, steps for calculating annualized capital cost of SOFC-GT system and annual profit are also provided in the Supplementary Information. For normal MOO of SOFC-GT system, fixed values of operating and market parameters are used: yearly operation $=6600(\mathrm{~h} / \mathrm{y})$, fuel cell life time $=6(\mathrm{y})$, other equipment life time $=18(\mathrm{y})$, interest rate $=0.06(\%)$, fuel cell capital cost uncertainty factor (represents uncertainty in the capital cost of fuel cell) $=0$, electricity price $=0.16$ $(\$ / \mathrm{kWh})$, oxygen price $=235(\$ / 3600 \mathrm{~kg})$ and bio-gas price $\left(0.62\right.$ mole fraction $\mathrm{CH}_{4}$ and remaining $\left.\mathrm{CO}_{2}\right)=420(\$ / 3600 \mathrm{~kg})$. For normal $\mathrm{MOO}$, there should not be any uncertainty in the capital cost of fuel cell (fixed value), so value of fuel cell capital cost uncertainty factor should be zero. The SOFC-GT system consumes $8.34 \times 10^{6} \mathrm{~kg}$ fuel per year $(=0.351$ $\mathrm{kg} / \mathrm{s}$ ), and it has electricity production of about $5 \mathrm{MW}$. Prices of cooling water 1 (30 -45 $\left.{ }^{\circ} \mathrm{C}\right)$ and cooling water $2\left(5-30^{\circ} \mathrm{C}\right)$ are 0.00016 and $0.02 \$ / \mathrm{kJ}$, respectively [15].

Fig. 3 presents the Pareto solutions for simultaneous maximization of annual profit and minimization of annualized capital cost. These Pareto solutions are obtained with: population size $=60$ and number of function evaluations $=5,000$. To give some idea about 
computational effort, CPU time taken by OSMOSE program for normal MOO is about 4.5 hours (Intel Core i7-5600U, CPU =2.6 GHz \& 2.6 GHz, RAM = $12 \mathrm{~GB}$ ). As expected, annual profit is conflicting with annualized capital cost. Fig. 3 also shows variations of important decision variables with annual profit; steam to carbon ratio for SR and fuel cell inlet temperature mainly causing the shape of Pareto front. A high steam to carbon ratio gives higher conversion of $\mathrm{CH}_{4}$, which increases profit margin and also the size/cost of the $\mathrm{SR}$ unit. SR outlet temperature, fuel utilization, CGT inlet temperature, pressure ratios for CGT and AGT turbines, are close to their upper bounds, and these are not shown in Fig. 3 for brevity. Finally, pressure ratios for AGT compressor, $\mathrm{CO}_{2}$ compressor 1 and $\mathrm{CO}_{2}$ compressor 2 are scattered with their bounds.

\section{INSERT Fig. 3}

It is worth mentioning that a corner solution on the Pareto front is an attractive choice, if decision maker wants to select a solution by analyzing the shape of Pareto front (i.e., no parametric uncertainty analysis), as corner solutions are generally most compromised solutions. The selection of one solution from the Pareto front can be done based on the experience of engineers or using a Pareto ranking approach, which often requires preferences about objectives and their ranges $[16,17]$.

\section{UNCERTAINTY ANALYSIS OF PARETO SOLUTIONS OBTAINED FROM NORMAL MOO}

The uncertain operating and market parameters can be described by probability distribution functions. There could be several uncertain operating and market parameters which can affect the performance of SOFC-GT system. In this study, eight important 
operating and market parameters are considered, for studying their sensitivities on the Pareto solutions. As different parts of the Pareto front represent different regions in the decision variable space, so only some solutions, covering all parts of the Pareto front, are considered for parametric uncertainty analysis. There are no integer decision variables in the optimization problem, which makes selection of some Pareto solutions for parametric uncertainty analysis appropriate. In total, 25 solutions are taken from the normal Pareto front for parametric uncertainty analysis, and these solutions are numbered from the left hand side to the right hand side, as shown in Fig. 4.

Table 2 presents probability distribution functions for eight uncertain parameters. More details on distribution functions for yearly operation, plant life time, interest rate and fuel cell capital cost uncertainty factor can be found in literature $[6,9]$. Further, nominal electricity price is taken from Switzerland, oxygen price is taken from Kirschner [18], and bio-gas price (0.62 mole fraction $\mathrm{CH}_{4}$ and remaining $\mathrm{CO}_{2}$ ) is computed based on the natural gas price. Finally, normal distributions are assumed for electricity, oxygen and bio-gas prices.

In order to perform the parametric uncertainty analysis of the Pareto solutions following steps are followed.

1. Store $\mathrm{P}_{\mathrm{i}}(\mathrm{FIX})$ value which is the annual profit for $\mathrm{i}^{\text {th }}$ Pareto solution.

2. Generate 500 economic scenarios (ES1, ES2... ES500) based on the probability distribution functions for operating and market parameters.

3. For ES1:

- For $i^{\text {th }}$ Pareto solution, calculate the annual profit value $=\mathrm{P}_{i}(\mathrm{ES} 1)$. 
- For $\mathrm{i}^{\text {th }}$ Pareto solution, calculate absolute relative change in the annual profit, as shown below:

$$
P_{i}(R C)=\left|\frac{P_{i}(E S 1)-P_{i}(F I X)}{P_{i}(F I X)}\right|
$$

- Lower value of $\mathrm{P}_{\mathrm{i}}(\mathrm{RC})$ for a particular Pareto solution indicates that it is less sensitive. Hence, arrange all the Pareto solutions in order of increasing absolute relative change in the annual profit.

- Select best and top 5 Pareto solutions, based on the lower value of $\mathrm{P}_{\mathrm{i}}(\mathrm{RC})$.

4. For ES2 to ES500: repeat Step 3, and identify the best and top 5 Pareto solutions.

5. For all 500 economicscenarios: calculate percentage to be the best Pareto solution (= number of times a particular Pareto solution is the best Pareto solution / total number of economic scenarios $\times 100)$, and percentage to be in top 5 Pareto solutions (=number of times a particular Pareto solution is in top 5 Pareto solutions / total number of economic scenarios $\times 100)$.

This parametric uncertainty analysis of the Pareto solutions will help decision maker to select one final solution/design for the implementation purpose. Fig. 4 presents the ranking of the Pareto solutions, based on the percentage to be the best Pareto solution and percentage to be in top 5 solutions, using 500 economic scenarios. It can be seen that Pareto solution 25 (with percentage to be best $=72$ ) has minimum absolute relative change in the annual profit. Pareto solution 25 is the best solution for 360 economic scenarios, out of 500 economic scenarios. Further, Pareto solutions 16 and 24 seem to be more robust solutions compared to the others. Mostly, Pareto solutions 16, 20-25 are the top 5 Pareto solutions, or they have higher percentage to be in top 5 Pareto solutions 
compared to the remaining Pareto solutions. In conclusion, Pareto solution 25 is the most robust (or least sensitive) solution, and can be chosen for the implementation purpose, based on this parametric uncertainty analysis.

\section{INSERT Fig. 4}

The SOFC-GT hybrid cycle shows excellent thermodynamic performance, and so the first law energy and exergy efficiencies of 25 Pareto solutions in Fig. 4 are calculated, and these values are presented in Table 3. Pareto solution 1 has the lowest values of both efficiencies, whereas Pareto solution 25 has the highest values of both efficiencies. Further, Fig. 5 shows composite curves for Pareto solution 25, and it can be seen that hot and cold composite curves are close to each other, and hot utility has not been used. The unconverted fuel from the anodic side of the fuel cell is burnt in a catalytic burner, and this heat is sufficient to close the energy balance of the system.

\section{INSERT Table 3 and Fig. 5}

\section{ROBUST MOO OF SOFC-GT}

In the robust MOO, variability associated with operating and market parameters is considered during the $\mathrm{MOO}$ search. Hence, the robust $\mathrm{MOO}$ approach should generate less sensitive Pareto solutions compared to the normal MOO approach. In the normal MOO approach, newly generated set of decision variables is passed to the SOFC-GT simulation in BELSIM-Vali. After the convergence of plant simulation, heat integration is performed among hot and cold process streams (see Fig. 2). Finally, objective functions 
are calculated (i.e., performance evaluation step) using values of decision variables, information obtained from the SOFC-GT simulation, results of heat integration and values of operating and market parameters. The search procedure is repeated for the specified number of function evaluations.

The robust MOO approach varies from the normal MOO approach only in the performance evaluation step. In the robust MOO approach, SOFC-GT simulation has to be converged only once for a particular set of decision variables generated by the MOO program, but many values of each objective function are possible depending on the number of set of operating and market parameters values. In this study, 200 set of operating and market parameters values are generated, using their probability distribution functions (Table 2). Hence, there are 200 values of each objective function, for a set of decision variables values. In otherwords, each solution in the decision variable space represents a cluster in the objective function space [7]. For a set of decision variables values, single point (or one value of each objective function) is required in the objective function space. Mean or median effective objective function can be used to represent the cluster as a single point in the objective function space. This study uses median effective objective function for representing objective function cluster into a single point. Note that 200 new set of operating and market parameters values are generated for each set of decision variables, using their probability distribution functions.

Fig. 6 presents the Pareto solutions obtained from robust MOO. It can be noticed that fewer number of Pareto solutions are obtained from robust MOO approach compared to the normal MOO approach (Fig. 3). The robust MOO gives only 10 Pareto 
solutions in the best Pareto front, and 11 Pareto solutions in the second best Pareto front. Note that Fig. 6 presents all the solutions obtained from robust MOO. The inclusion of parametric uncertainty during MOO search prevents having many solutions in the best Pareto front. Hence, convergence of the robust $\mathrm{MOO}$ is slower than normal MOO. Both normal and robust MOO searchers were terminated based on maximum number for function evaluations.

\section{INSERT Fig. 6}

All the solutions in the first and second best Pareto fronts obtained from robust MOO are chosen to perform the parametric uncertainty analysis. These Pareto solutions are numbered from the left hand side to the right hand side, in both the Pareto fronts (Fig. 7). The procedure for parametric uncertainty analysis has been described earlier. Fig. 7 shows the ranking of the Pareto solutions, based on the percentage to be the best Pareto solution and percentage to be in top 5 Pareto solutions, using 500 economic scenarios. Pareto solution 11 has minimum absolute relative change in the annual profit. In 500 economic scenarios, Pareto solution 11 is the best solution for 307 (61.4\%) economic scenarios. Pareto solutions $1(14.8 \%)$ and $8(10 \%)$ are other good solutions, based on the percentage to be the best Pareto solution. Further, Pareto solutions 1, 3, 11, 12 and 14 have nearly same percentage to be in top 5 Pareto solutions, and this percentage is significantly better compared to the remaining Pareto solutions.

\section{INSERT Fig. 7}


For Pareto solutions in Fig. 7, the first law energy and exergy efficiencies are calculated, and they are presented in Table 3. Here, Pareto solution 2 has the highest values of both the efficiencies in comparison to the other solutions. Note that Pareto solutions obtained from normal $\mathrm{MOO}$ approach has higher values of efficiencies compared to Pareto solutions obtained from robust MOO approach, as normal MOO approach has better convergence. Fig. 5 shows composite curves for Pareto solution 11, and it can be seen that hot and cold composite curves are close to each other, and there is no use of hot utility. Hot utility is available at $1600^{\circ} \mathrm{C}$, and composite curves show that it has not been required to close the heat balance.

\section{COMPARISON OF PARETO SOLUTIONS OBTAINED FROM NORMAL AND ROBUST MOO}

Normal and robust Pareto solutions for SOFC-GT system are respectively presented in Fig. 3 and 6. In order to compare the Pareto solutions obtained from both approaches, 25 Pareto solutions are chosen from the normal Pareto front (Fig. 4), and 21 Pareto solutions are chosen from the robust Pareto front (Fig. 7). The parametric uncertainty analysis is performed on the selected Pareto solutions, using the procedure described earlier. Fig. 8 presents the ranking of the Pareto solutions, based on the percentage to be the best Pareto solution and percentage to be in top 5 Pareto solutions, using 500 economic scenarios. Pareto solution 11 obtained from the robust MOO approach (with percentage to be the Pareto best solution $=54.4 \%$ ) have minimum absolute relative change in the annual profit. Further, Pareto solutions 1 and 8 obtained from the robust MOO are other less sensitive solutions (with percentage to be the best solution $=14 \%$ and $8.8 \%$ ). Pareto solutions 1, 3, 11, 12 (robust MOO) and 25 (normal MOO) have nearly 
same percentage to be in top 5 Pareto solutions, and their scores are much better than other Pareto solutions. It is evident from this parametric uncertainty analysis that Pareto solution 11 (robust $\mathrm{MOO}$ ) is the most robust (or least sensitive) solution, and so it can be chosen for the implementation purpose.

\section{INSERT Fig. 8}

For two Pareto solutions, Fig. 9 presents histograms of relative change in the annual profitfor 500 economicscenarios. The mean values of relative change in the annual profit for Pareto solutions 25 (normal MOO) and 11 (robust MOO) are -0.127 and 0.048 , which indicates that Pareto solution 11 is more robust compared to Pareto solution 25 . This has also been demonstrated by the parametric uncertainty analysis to compare the Pareto solutions obtained from normal and robust MOO approaches.

\section{INSERT Fig. 9}

\section{IMPACT OF PLANT SIZE ON PLANT ECONOMY}

In order to understand the impact of the plant size on the plant economy, SOFC-GT hybrid cycle has been optimized for different electricity production rates. For this comparison, levelized electricity cost and annualized capital cost per kWh were considered as objective functions in the MOO problem (with same decision variables and ranges, as shown in Table 1). Fig. 10 presents box plot for levelized electricity cost (obtained from normal MOO) with respect to five different electivity output from SOFCGT hybrid cycle.

INSERT Fig. 10 


\section{CONCLUSIONS}

This study optimizes performance of SOFC-GT system for maximization of annual profit and minimization of annualized capital cost, simultaneously. In order to identify flexible Pareto solution, parametric uncertainty analysis is used to rank the Pareto solutions. Robust MOO of SOFC-GT system is also performed to generate less sensitive Pareto solutions, by including operating and market variabilities during the optimization procedure. Finally, Pareto solutions from the normal and robust Pareto fronts are ranked based on the percentage to be best solution and to be in top 5 solutions, using 500 economic scenarios. Pareto solutions from the robust MOO search found to be less sensitive compared to Pareto solutions from the normal MOO search. The parametric uncertainty analysis is able to identify less sensitive Pareto solutions for the implementation purpose.

\section{ACKNOWLEDGMENT}

The first author is grateful for the financial support provided by the Swiss National Science Foundation (National Research Programmes 66 Resource Wood - Project 136670).

\section{NOMENCLATURE}

$\begin{array}{ll}\text { ACC } & \text { Annualized Capital Cost } \\ A G T & \text { Anodic Gas Turbine } \\ A P & \text { Annual Profit } \\ C G T & \text { Cathodic Gas Turbine } \\ E S & \text { Economic Scenario } \\ G T & \text { Gas Turbine } \\ \text { LEC } & \text { Levelized Electricity Cost } \\ \text { MOO } & \text { Multi-Objective Optimization }\end{array}$




$\begin{array}{ll}\text { NG } & \text { Natural Gas } \\ \text { RMOO } & \text { Robust Multi-Objective Optimization } \\ \text { SNG } & \text { Synthetic Natural Gas } \\ \text { SOFC } & \text { Solid Oxide Fuel Cell } \\ \text { SR } & \text { Steam Reforming }\end{array}$

\section{REFERENCES}

[1] Sharma, S., Rangaiah, G.P., 2013, "Multi-Objective Optimization Applications in Chemical Engineering," In Rangaiah G.P. and Bonilla-Petriciolet, A. (editors), MultiObjective Optimization in Chemical Engineering: Developments and Applications, Wiley.

[2] Facchinetti, E., Favrat, D., Maréchal, F., 2014, “Design and Optimization of an Innovative Solid Oxide Fuel Cell-Gas Turbine Hybrid Cycle for Small Scale Distributed Generation," Fuel Cells, 14(4), pp. 595-606.

[3] Ramadhani, F., Hussain, M.A., Mokhlis, H., Hajimolana, S., 2017, “Optimization Strategies for Solid Oxide Fuel Cell (SOFC) Application: A Literature Survey," Renewable and Sustainable Energy Reviews, 76, pp. 460-484.

[4] Marchetti, A., Gopalkrishnan, A., Chachuat, B., Bonvin, D., Tsikonis, L., Nakajo, A., Wuillemin, Z., Van herle, J., 2011, "Robust Real-Time Optimization of a Solid Oxide Fuel Cell Stack", J. Fuel Cell Science and Technology, 8(5).

[5] Hajabdollahi, Z., Fu, P.F., 2017, "Multi-objective based Configuration Optimization of SOFC-GT Cogeneration Plant," Applied Thermal Engineering, 112, pp. 549-559.

[6] Tock, L., Maréchal, F., 2015, "Decision Support for Ranking Pareto Optimal Process Designs Under Uncertain Market Conditions," Computers \& Chemical Engineering, 83, pp. 165-175.

[7] Mitra, K., 2013, "Chance Constrained Programming to Handle Uncertainty in Nonlinear Process Models," In Rangaiah G.P. and Bonilla-Petriciolet, A. (editors), Multi-Objective Optimization in Chemical Engineering: Developments and Applications, Wiley.

[8] Palazzi, F., Autissier, N., Maréchal, F., Favrat, D., 2007, "A Methodology for ThermoEconomic Modeling and Optimization of Solid Oxide Fuel Cell Systems," Applied Thermal Engineering, 27(16), pp. 2703-2712.

[9] Caliandro, P., Tock, L., Ensinas, A.V., Maréchal, F., 2014, "Thermo-Economic Optimization of a Solid Oxide Fuel Cell - Gas Turbine System Fueled with Gasified Lignocellulosic Biomass," Energy Conversion and Management, 85, pp. 764-773.

[10] Deb, K., Gupta, H., 2006, “Introducing Robustness in Multi-Objective Optimization," Evolutionary Computation, 14(4), pp. 463-494. 
[11] Sharma, S., Celebi, A.D., Maréchal, F. 2017, "Robust Multi-Objective Optimization of Gasifier and Solid Oxide Fuel Cell Plant for Electricity Production Using Wood," Energy, 137, pp. 811-822.

[12] Van herle, J., Maréchal, M., Leuenberger, S., Favrat, D., 2003, "Energy Balance Model of a SOFC Cogenerator Operated with Biogas," Journal of Power Sources, 118(1-2), pp. 375-383.

[13] Pelster, S., 1998, "Environomic Modeling and Optimization of Advanced Combined Cycle Cogeneration Power Plants Including $\mathrm{CO}_{2}$ Separation Options," EPFL Thesis, pp. 8990.

[14] Maréchal, F., Palazzi, F., Godat, J. and Favrat, D., 2004, "Thermo-Economic Modelling and Optimization of Fuel Cell Systems," Fuel Cells, 5(1), pp. 5-24.

[15] Turton, R., Bailie, R. C., Whiting, W. B., Shaeiwitz, J. A., 2012, "Analysis, Synthesis and Design of Chemical Processes," 4th ed., Prentice Hall.

[16] Rangaiah, G.P., Sharma, S. and Sreepathi, B.K., 2015, “Multi-Objective Optimization for the Design and Operation of Energy Efficient Chemical Processes and Power Generation," Current Opinion in Chemical Engineering, 10, pp. 49-62.

[17] Wang, Z., Rangaiah, G.P., 2017, "Application and Analysis of Methods for Selecting an Optimal Solution from the Pareto-optimal Front Obtained by Multi-Objective Optimization," Ind. Eng. Chem. Res., 56(2), pp. 560-574.

[18] Kirschner, M., 2012, "Oxygen. In: Ullmann's Encyclopedia of Industrial Chemistry," Wiley-VCH. 


\section{Figure Caption List}

Fig. 1 A simplified schematic of solid oxide fuel cell with gas turbine (1: SR, 2: SOFC, 3: CGT, 4: AGT and 5: $\mathrm{CO}_{2}$ compression): stream data correspond to Pareto solution 25 in Fig. 4

Fig. 2 (a) MOO of SOFC-GT system using OSMOSE program, which has four main parts: MOO program, plant simulation, energy integration and performance evaluation, (b) parametric uncertainty analysis methodology

Fig. 3 Pareto solutions obtained for SOFC-GT system from normal MOO

Fig. 4 Uncertainty analysis of chosen SOFC-GT designs obtained from normal MOO

Fig. 5 Composite curves for Pareto solutions 25 (normal MOO, Fig. 4) and 11 (robust MOO, Fig. 7)

Fig. 6 All solutions obtained for SOFC-GT system from robust MOO

Fig. 7 Uncertainty analysis of chosen SOFC-GT designs obtained from robust MOO

Fig. 8 Ranking of chosen SOFC-GT designs obtained from normal and robust MOO approached

Fig. 9 Relative change in the annual profit for Pareto solutions 25 (normal MOO, Fig. 4) and 11 (robust MOO, Fig. 7)

Fig. 10 Effect of SOFC-GT plant size on the levelized electricity cost (Box Plot)

\section{Table Caption List}

Table 1 Multi-objective problem formulation for SOFC-GT system

Table 2 Definition of probability distribution functions for uncertain operating and market parameters

Table 3 First law energy and exergy efficiency of Pareto solutions in Fig. 4 and 7 
Table 1

\begin{tabular}{|c|c|c|c|c|}
\hline \multicolumn{5}{|c|}{ Objective Function } \\
\hline \multirow{2}{*}{$\begin{array}{l}\text { Maximize } \\
\text { Minimize }\end{array}$} & \multicolumn{4}{|l|}{ Annual Profit (\$/y) } \\
\hline & \multicolumn{4}{|c|}{ Annualized capital cost (\$/y) } \\
\hline \multicolumn{2}{|c|}{ Decision Variable (DV) } & SOFC-GT Part & Lower Bound & Upper Bound \\
\hline \multicolumn{2}{|c|}{ Steam to carbon ratio for SR } & SR & 1.0 & 3.0 \\
\hline \multicolumn{2}{|c|}{ SR outlet temperature (K) } & SR & 800 & 950 \\
\hline \multicolumn{2}{|c|}{ Fuel cell inlet temperature (K) } & SOFC & 950 & 1000 \\
\hline \multicolumn{2}{|c|}{ Fuel utilization } & SOFC & 0.5 & 0.75 \\
\hline \multicolumn{2}{|c|}{ CGT inlet temperature (K) } & CGT & 1100 & 1400 \\
\hline \multicolumn{2}{|c|}{ Pressure ratio for CGT turbine } & CGT & 4 & 5 \\
\hline \multicolumn{2}{|c|}{ Pressure ratio for AGT turbine } & AGT & 4 & 5 \\
\hline \multicolumn{2}{|c|}{ Pressure ratio for AGT compressor } & AGT & 4 & 5 \\
\hline \multicolumn{2}{|c|}{ Pressure ratio for $\mathrm{CO}_{2}$ compressor 1} & $\mathrm{CO}_{2}$ Compression & 4 & 5 \\
\hline \multicolumn{2}{|c|}{ Pressure ratio for $\mathrm{CO}_{2}$ compressor 2} & $\mathrm{CO}_{2}$ Compression & 4 & 5 \\
\hline
\end{tabular}

Table 2

\begin{tabular}{llll}
\hline Uncertain Parameters & & \multicolumn{2}{l}{ Probability Distribution Functions } \\
\hline Yearly operation & $(\mathrm{h} / \mathrm{y})$ & Beta & $\mathrm{c}=8600, \alpha=3.9, \beta=1.2$ \\
Interest rate & $(\%)$ & Normal & $\mu=0.06, \sigma=0.01$ \\
Fuel cell life time & $(\mathrm{y})$ & Beta & $\mathrm{c}=10, \alpha=5.8, \beta=4$ \\
Other equipment life time & $(\mathrm{y})$ & Beta & $\mathrm{c}=30, \alpha=5.8, \beta=4$ \\
FC capital cost uncertainty factor & - & Uniform & $\mathrm{a}=-0.3, b=0.3$ \\
Electricity price & $(\$ / \mathrm{kWh})$ & Normal & $\mu=0.16, \sigma=0.02$ \\
Oxygen price & $(\$ / 3600 \mathrm{~kg})$ & Normal & $\mu=235, \sigma=50$ \\
Bio-gas price & $(\$ / 3600 \mathrm{~kg})$ & Normal & $\mu=420, \sigma=100$ \\
\hline
\end{tabular}


Table 3

\begin{tabular}{|c|c|c|c|c|c|}
\hline \multicolumn{3}{|c|}{ Selected Pareto Solutions in Fig. 4} & \multicolumn{3}{|c|}{ Selected Pareto Solutions in Fig. 7} \\
\hline $\begin{array}{c}\text { Solution } \\
\text { No }\end{array}$ & $\begin{array}{c}\text { First Law } \\
\text { Energy } \\
\text { Efficiency }\end{array}$ & $\begin{array}{c}\text { Exergy } \\
\text { Efficiency }\end{array}$ & $\begin{array}{c}\text { Solution } \\
\text { No }\end{array}$ & $\begin{array}{l}\text { First Law } \\
\text { Energy } \\
\text { Efficiency }\end{array}$ & $\begin{array}{c}\text { Exergy } \\
\text { Efficiency }\end{array}$ \\
\hline 1 & 71.90 & 64.80 & 1 & 70.22 & 63.28 \\
\hline 2 & 71.97 & 64.86 & 2 & 73.89 & 66.59 \\
\hline 3 & 72.17 & 65.04 & 3 & 70.87 & 63.87 \\
\hline 4 & 72.43 & 65.28 & 4 & 71.91 & 64.81 \\
\hline 5 & 72.56 & 65.39 & 5 & 73.39 & 66.14 \\
\hline 6 & 72.68 & 65.50 & 6 & 71.53 & 64.46 \\
\hline 7 & 72.87 & 65.67 & 7 & 71.81 & 64.72 \\
\hline 8 & 72.99 & 65.78 & 8 & 71.79 & 64.70 \\
\hline 9 & 73.11 & 65.88 & 9 & 71.81 & 64.71 \\
\hline 10 & 73.27 & 66.03 & 10 & 72.07 & 64.95 \\
\hline 11 & 73.40 & 66.15 & 11 & 69.88 & 62.97 \\
\hline 12 & 73.57 & 66.30 & 12 & 71.69 & 64.61 \\
\hline 13 & 73.74 & 66.45 & 13 & 71.96 & 64.85 \\
\hline 14 & 73.85 & 66.56 & 14 & 71.88 & 64.78 \\
\hline 15 & 74.01 & 66.70 & 15 & 71.31 & 64.26 \\
\hline 16 & 74.21 & 66.88 & 16 & 71.64 & 64.56 \\
\hline 17 & 74.27 & 66.93 & 17 & 71.90 & 64.79 \\
\hline 18 & 74.44 & 67.08 & 18 & 71.58 & 64.51 \\
\hline 19 & 74.62 & 67.25 & 19 & 73.01 & 65.80 \\
\hline 20 & 74.72 & 67.34 & 20 & 72.58 & 65.41 \\
\hline 21 & 74.83 & 67.43 & 21 & 72.80 & 65.61 \\
\hline 22 & 75.02 & 67.61 & & & \\
\hline 23 & 75.16 & 67.74 & & & \\
\hline 24 & 75.43 & 67.98 & & & \\
\hline 25 & 75.43 & 67.98 & & & \\
\hline
\end{tabular}




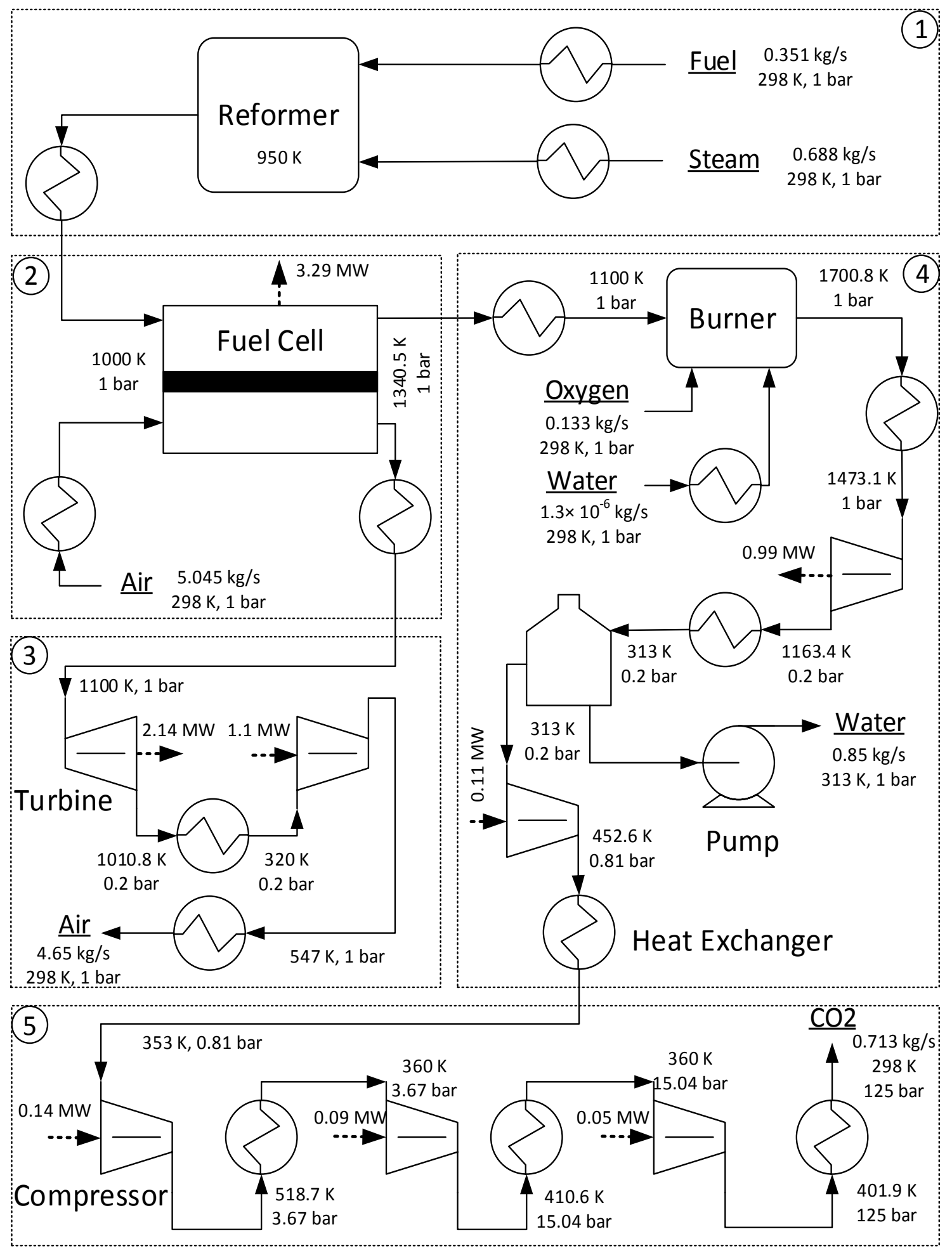

Fig. 1 
(a)

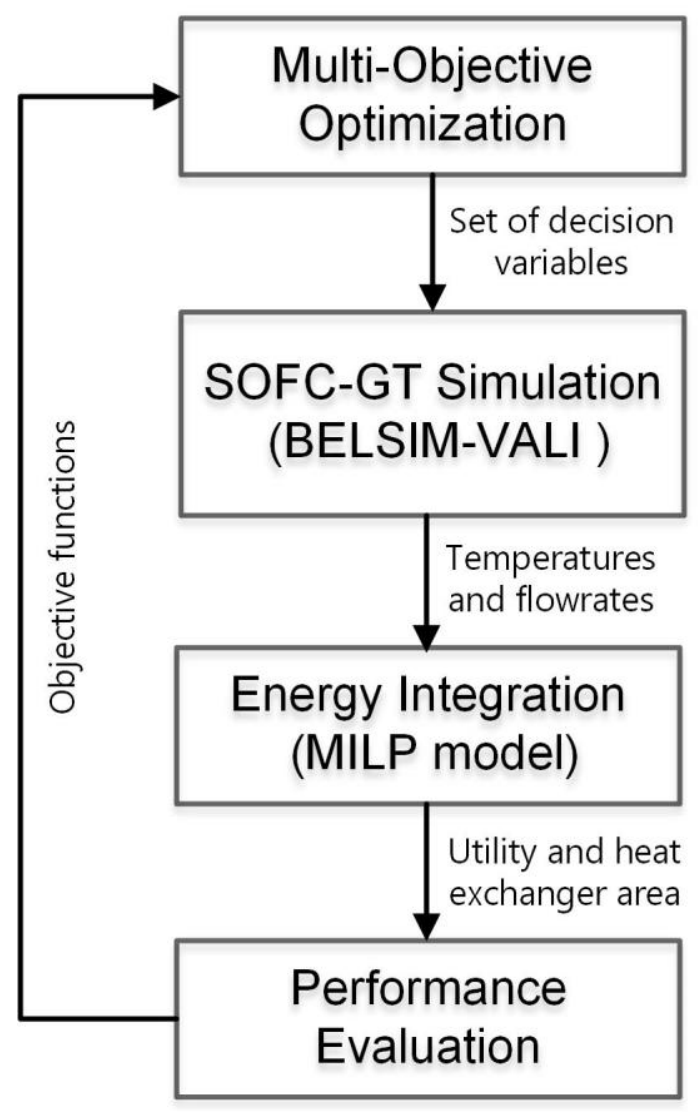

(b)
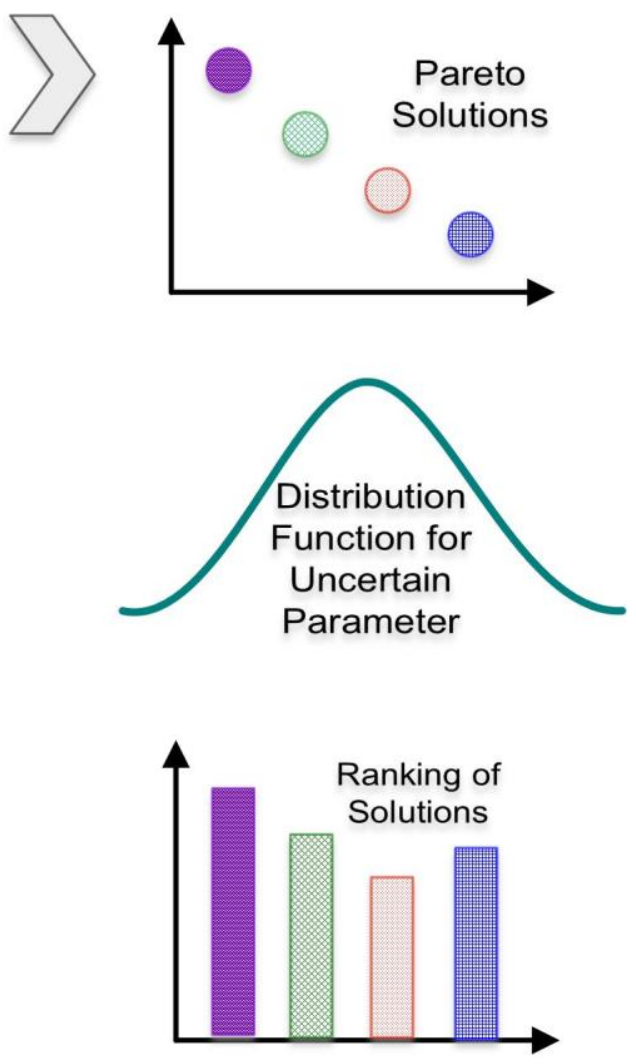

Fig. 2 

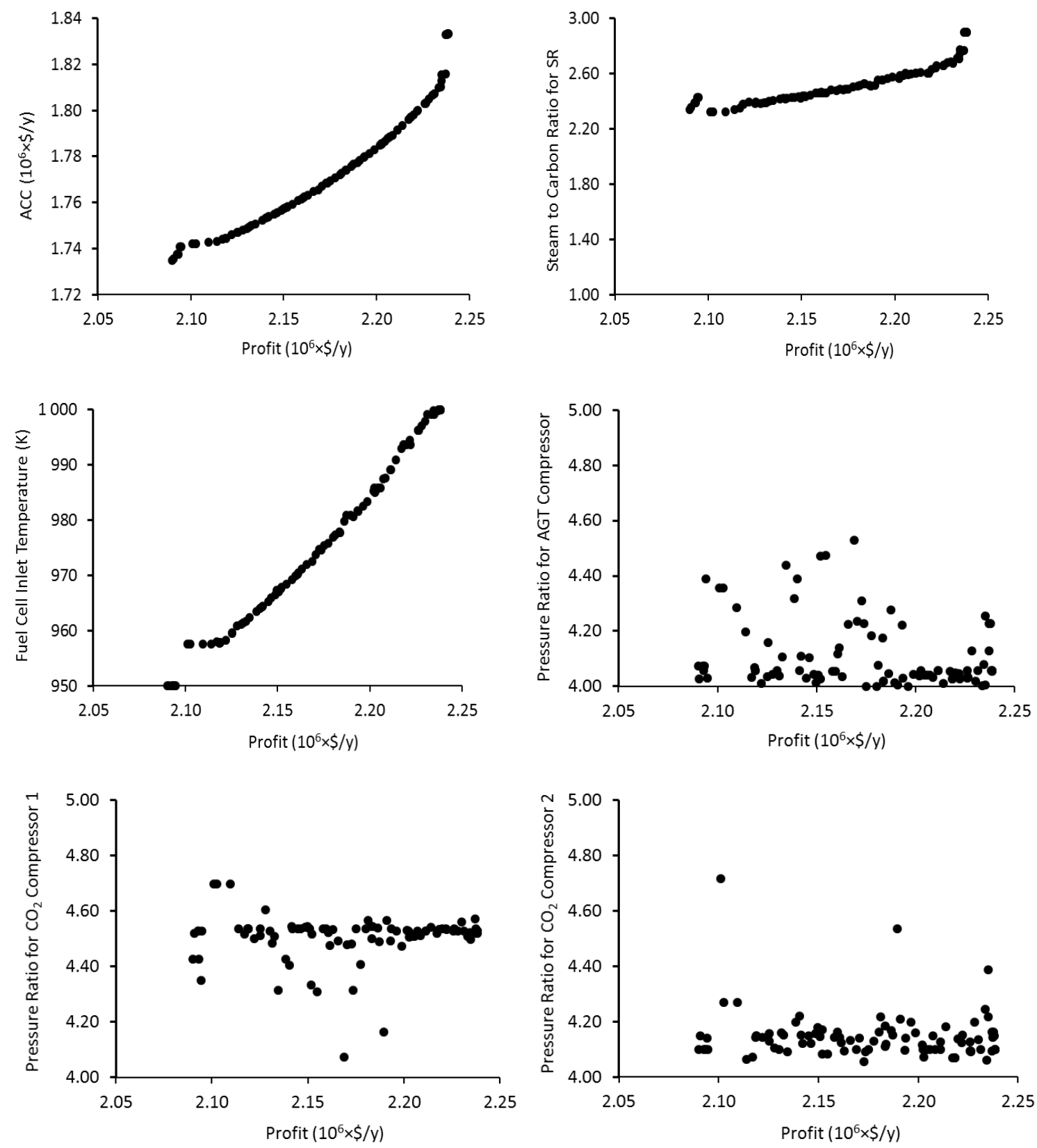

Fig. 3 

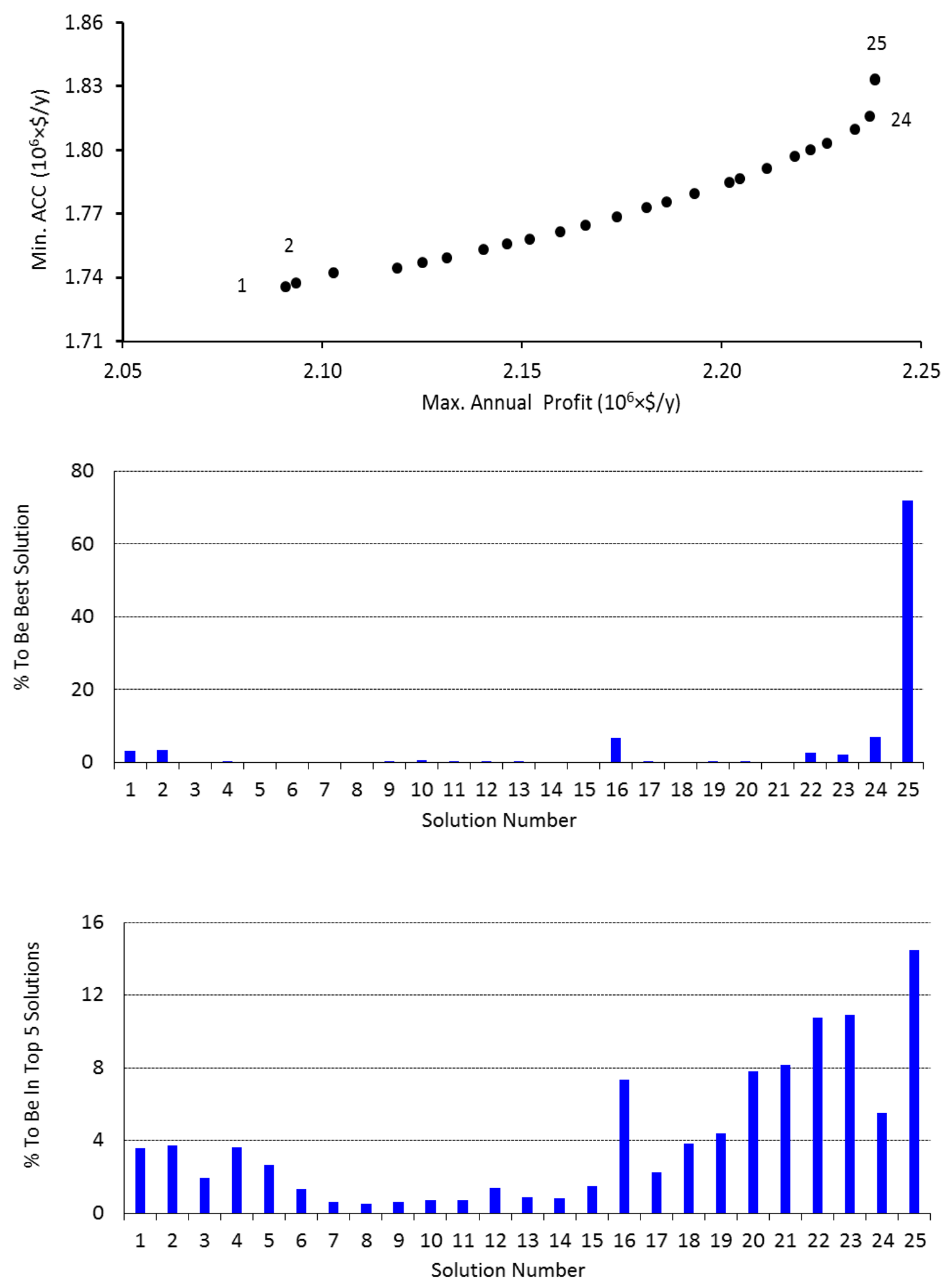

Fig. 4 

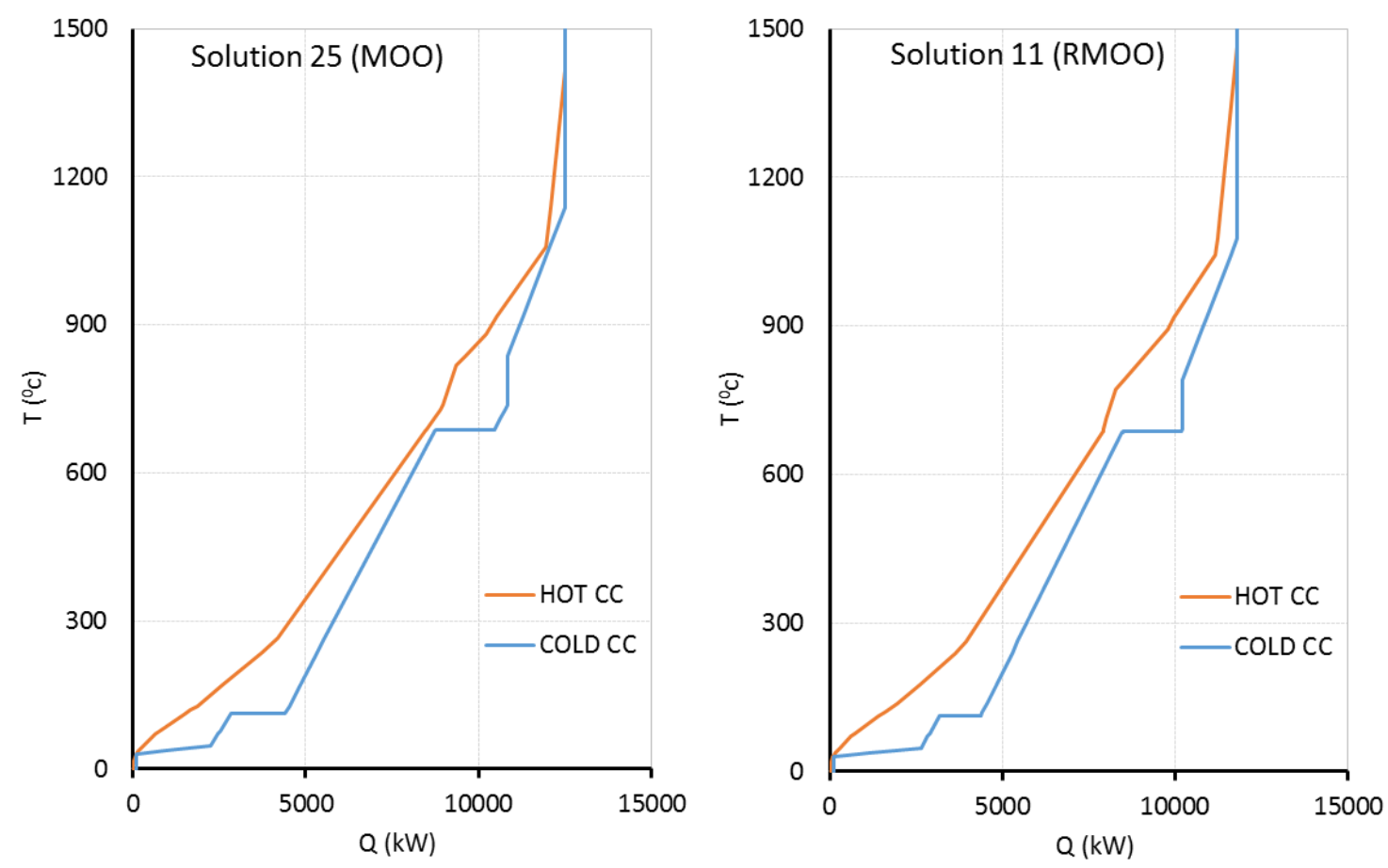

Fig. 5

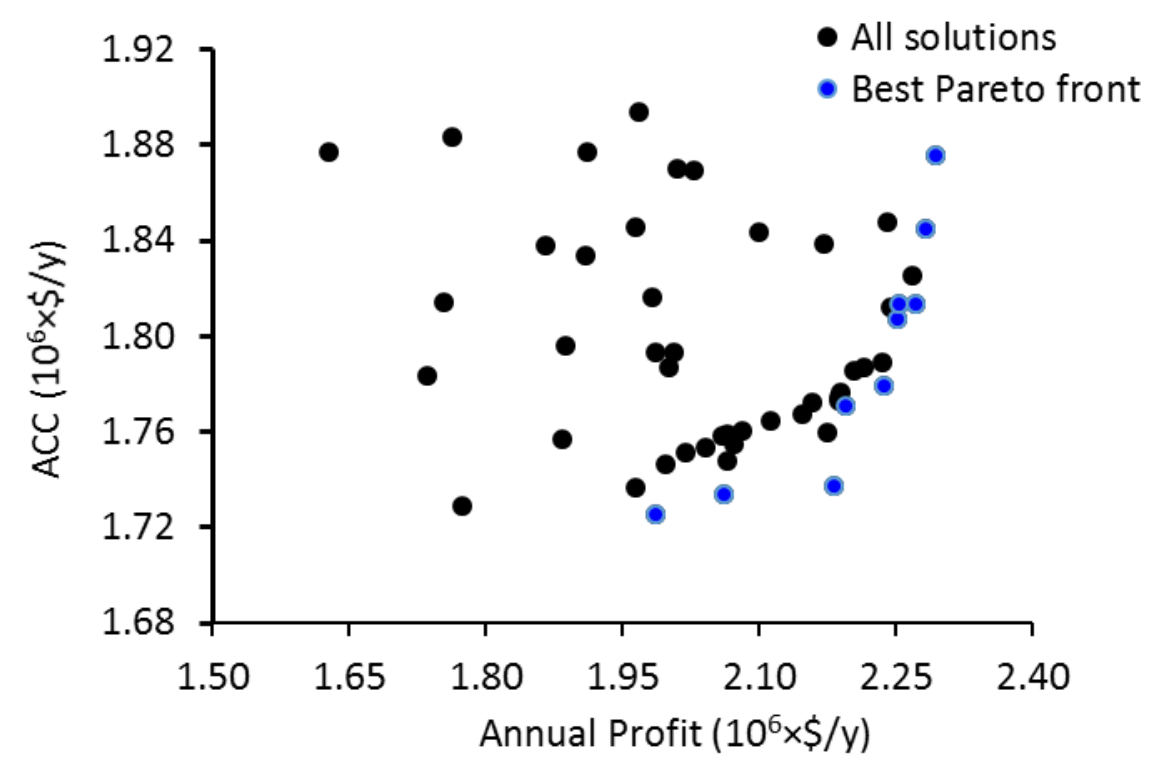

Fig. 6 

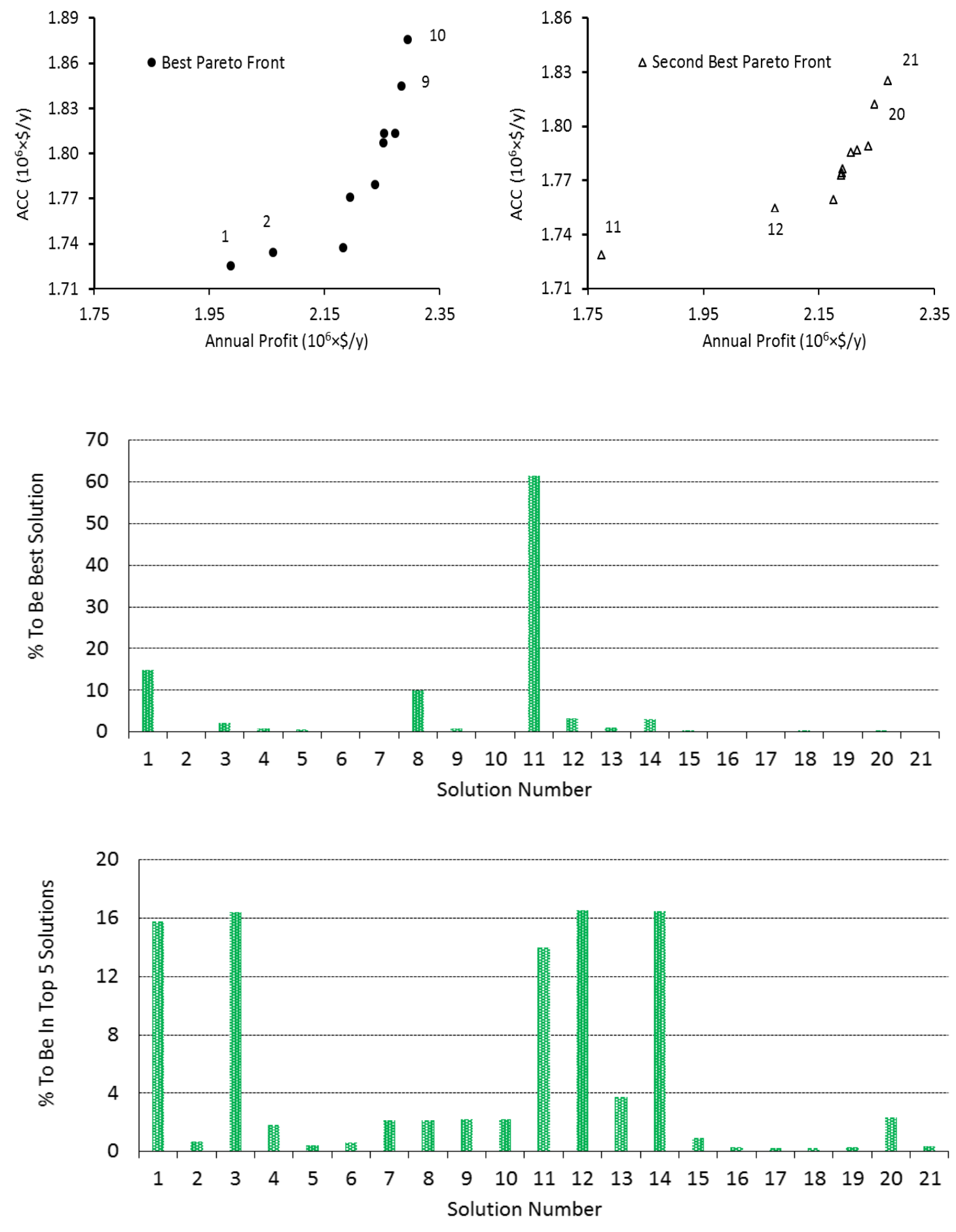

Fig. 7 


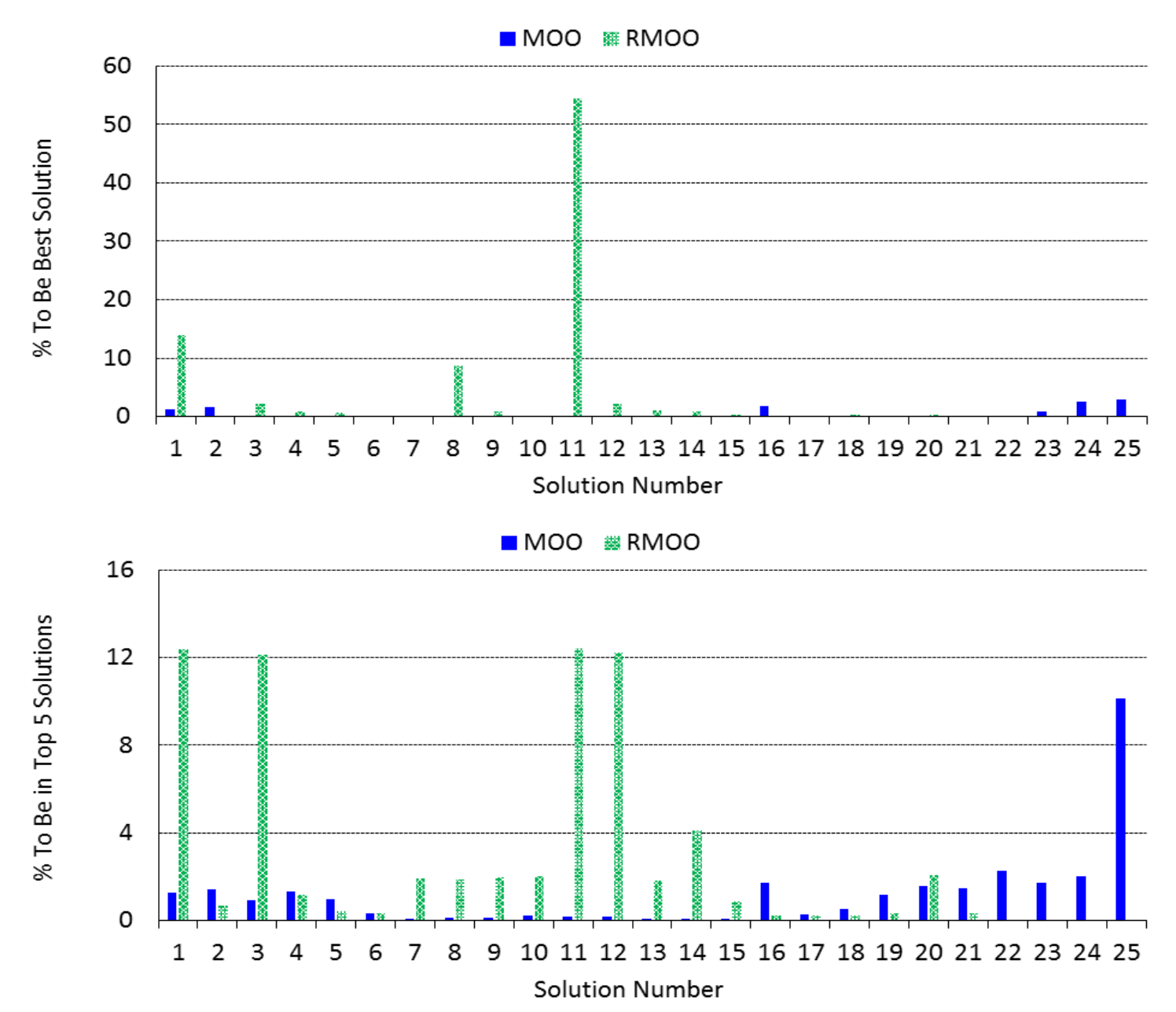

Fig. 8 

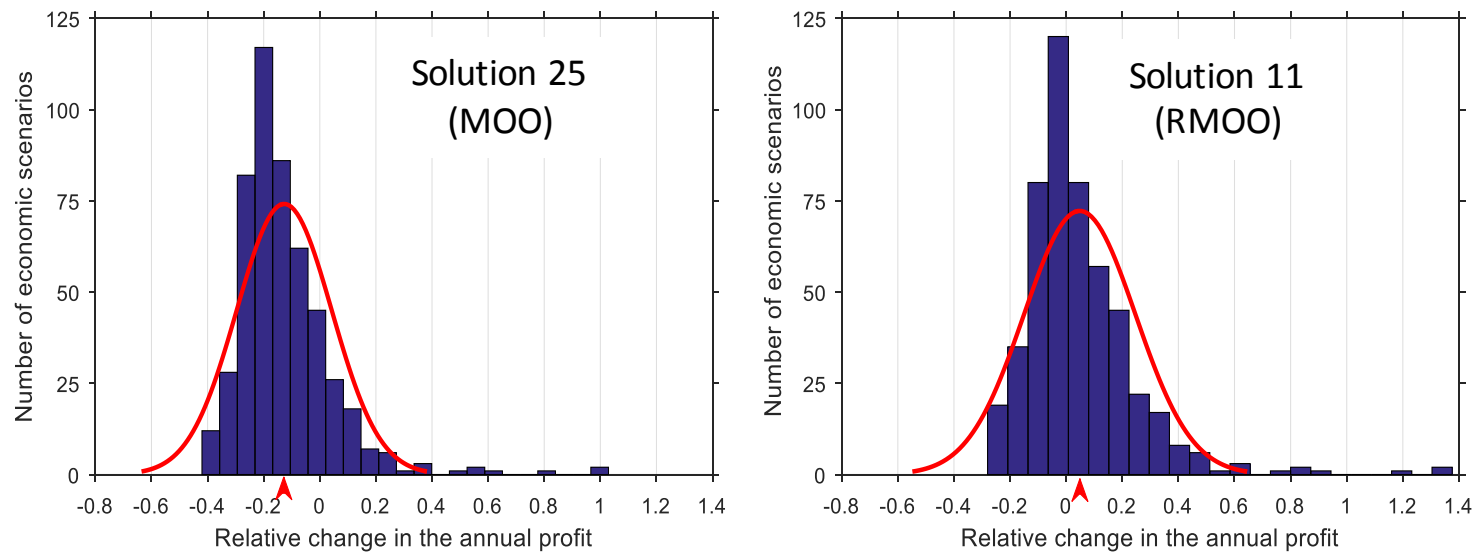

Fig. 9

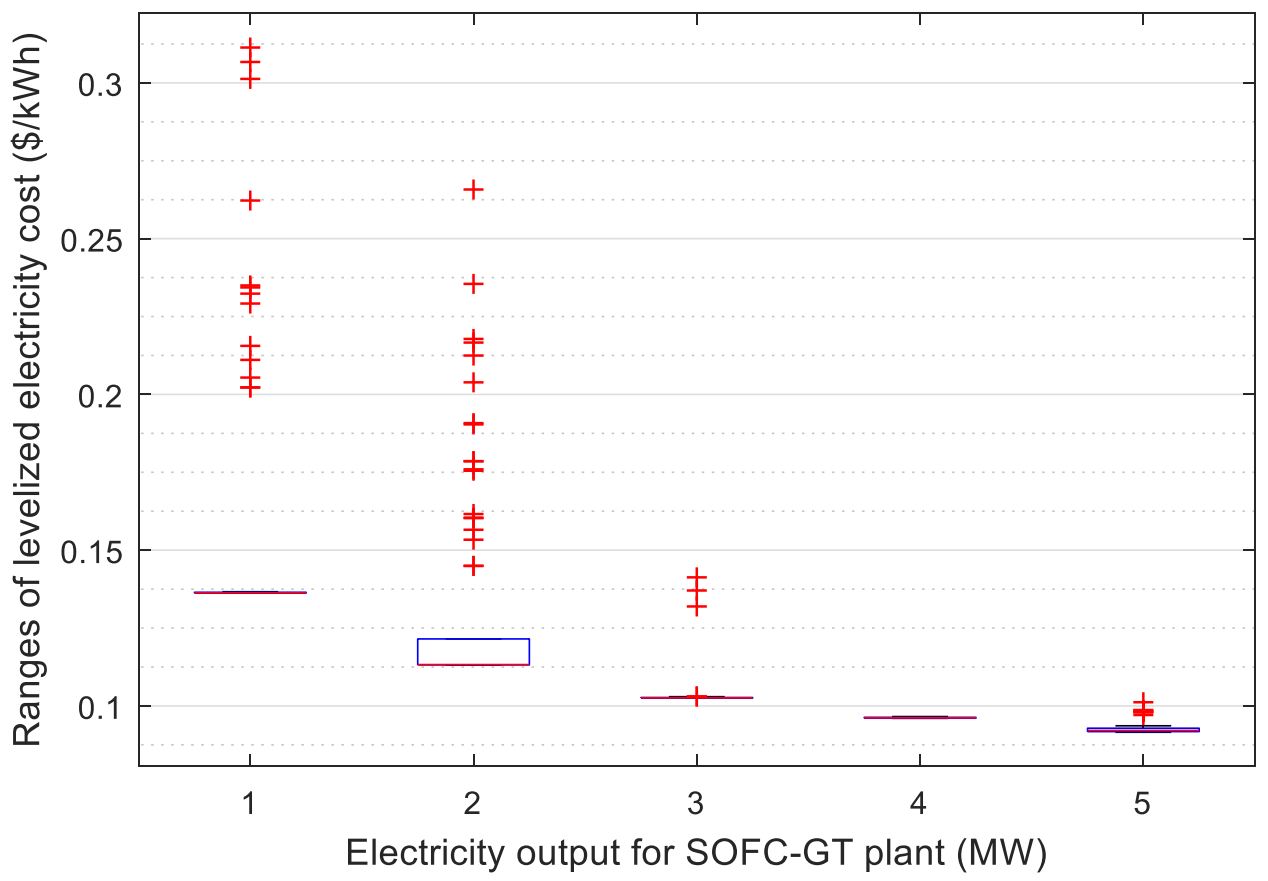

Fig. 10 


\section{Supplementary Information}

\section{A. Costing of SOFC-GT System}

\section{Traditional Process Units [1]}

$\operatorname{CEPCl}(2001)=397, \mathrm{CEPCl}=600, \mathrm{~F}_{\mathrm{CEPCl}}=600 / 397$

Bare module cost $\mathrm{C}_{\mathrm{BM}}=\mathrm{F}_{\mathrm{BM}} \cdot \mathrm{Cp}$

Total module cost $\mathrm{C}_{\mathrm{TM}}=1.18 \mathrm{C}_{\mathrm{BM}}$

Grassroots cost $\mathrm{C}_{\mathrm{GR}}=\mathrm{C}_{\mathrm{TM}}+0.5 \mathrm{C}_{\mathrm{BM}}$

\subsection{Axial Gas Turbine Costing: (Power \& Material)}

$\mathrm{F}_{\mathrm{BM}}: \mathrm{CS}=3.5, \mathrm{SS}=6.1, \mathrm{Ni}$ Alloy $=11.7$

$\mathrm{k} 1=2.7051, \mathrm{k} 2=1.4398, \mathrm{k} 3=-0.1776\left[\mathrm{~W}_{\min }=100 \mathrm{~kW}\right.$ and $\left.\mathrm{W}_{\max }=4000 \mathrm{~kW}\right]$

Purchase cost $C_{p}=F_{C E P C I} \cdot 10^{k 1+k 2 \cdot \log _{10}(A)+k 3 \cdot\left[\log _{10}(A)\right]^{2}}$

\subsection{Electric-Open/Drip-Proof Drive Costing: (Power)}

$\mathrm{F}_{\mathrm{BM}}=1.5$

$\mathrm{k} 1=2.9508, \mathrm{k} 2=1.0688, \mathrm{k} 3=-0.1315\left[\mathrm{~W}_{\min }=75 \mathrm{~kW}\right.$ and $\left.\mathrm{W}_{\max }=2600 \mathrm{~kW}\right]$

Purchase cost $\mathrm{C}_{\mathrm{p}}=\mathrm{F}_{\mathrm{CEPCI}} \cdot 10^{\mathrm{k} 1+\mathrm{k} 2 \cdot \log _{10}(\mathrm{~A})+\mathrm{k} 3 \cdot\left[\log _{10}(\mathrm{~A})\right]^{2}}$

\subsection{Reciprocating Compressor Costing: (Power \& Material)}

$\mathrm{F}_{\mathrm{BM}}: \mathrm{CS}=3.4, \mathrm{SS}=7, \mathrm{Ni}$ Alloy $=13.9$

$\mathrm{k} 1=2.2897, \mathrm{k} 2=1.3604, \mathrm{k} 3=-0.1027\left[\mathrm{~W}_{\min }=450 \mathrm{~kW}\right.$ and $\left.\mathrm{W}_{\max }=3000 \mathrm{~kW}\right]$

Purchase cost $C_{p}=F_{C E P C I} \cdot 10^{k 1+k 2 \cdot \log _{10}(A)+k 3 \cdot\left[\log _{10}(A)\right]^{2}}$

\subsection{Centrifugal Pump Costing: (Power, Material \& Pressure)}

$\mathrm{F}_{\mathrm{M}}: \mathrm{Cl}=1, \mathrm{CS}=1.6, \mathrm{SS}=2.3, \mathrm{Ni}$ Alloy $=4.4$

$\mathrm{C} 1=-0.3935, \mathrm{C} 2=0.3957, \mathrm{C} 3=-0.00226$

If $\mathrm{P}<10$ barg then $\mathrm{F}_{\mathrm{P}}=1$ else $\mathrm{F}_{\mathrm{P}}=10^{\mathrm{C} 1+\mathrm{C} 2 \cdot \log _{10}(\mathrm{P})+\mathrm{C} 3 \cdot\left[\log _{10}(\mathrm{P})\right]^{2}}, \mathrm{P}$ in barg

$\mathrm{B} 1=1.89, \mathrm{~B} 2=1.35$

$\mathrm{F}_{\mathrm{BM}}=\mathrm{B} 1+\mathrm{B} 2 \cdot \mathrm{F}_{\mathrm{M}} \cdot \mathrm{F}_{\mathrm{P}}$

$\mathrm{k} 1=3.3892, \mathrm{k} 2=0.0536, \mathrm{k} 3=0.1538\left[\mathrm{P}_{\max }=100 \mathrm{barg}, \mathrm{W}_{\min }=1 \mathrm{~kW}\right.$ and $\left.\mathrm{W}_{\max }=300 \mathrm{~kW}\right]$

Purchase cost $C_{p}=F_{C E P C I} \cdot 10^{k 1+k 2 \cdot \log _{10}(A)+k 3 \cdot\left[\log _{10}(A)\right]^{2}}$

\section{Fuel Cell Costing: (Power \& $\mathbf{N}_{\text {cell }}$ [2]}

$\operatorname{CEPCI}(2001)=397, \mathrm{FCEPCI}_{(1)}=600 / 397 \& \operatorname{CEPCI}(2007)=525, \mathrm{~F}_{\mathrm{CEPCI}(2)}=600 / 525$

$\mathrm{F}_{\mathrm{BM}}=2.7$

If $P<10$ barg then $F_{P}=1$

$\mathrm{F}_{\mathrm{T}}=1$ 
$\mathrm{k} 1=2.3859, \mathrm{k} 2=0.9721, \mathrm{k} 3=-0.0206\left[\mathrm{Q}_{\min }=3000 \mathrm{~kW}\right.$ and $\left.\mathrm{Q}_{\max }=100,000 \mathrm{~kW}\right]$

Housing volume cost $\mathrm{C}_{\mathrm{p}}$ (volume) $=\mathrm{F}_{\mathrm{CEPCI}(1)} \cdot 10^{\mathrm{k} 1+\mathrm{k} 2 \cdot \log _{10}(\mathrm{~A})+\mathrm{k} 3 \cdot\left[\log _{10}(\mathrm{~A})\right]^{2}}$

Bare module cost $C_{B M}($ Volume $)=\left(F_{B M} \cdot F_{P} \cdot F_{T}\right) \cdot C_{p}($ Volume $)$

$\mathrm{C}_{\text {cell }}=\mathrm{A}_{\mathrm{cell}} \cdot \mathrm{C}_{\mathrm{fc}, \mathrm{spec}}$

$\mathrm{N}_{\text {stack }}=\mathbf{N}_{\text {cell }} / \mathbf{N}_{\text {cell, } \text { max }}$

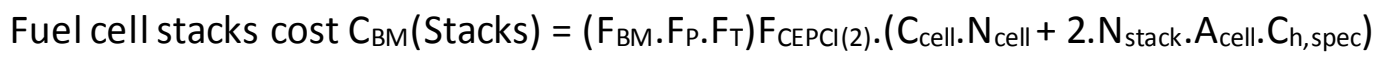

Total module cost $\mathrm{C}_{\mathrm{TM}}=1.18\left(\mathrm{C}_{\mathrm{BM}}(\right.$ Volume $)+\mathrm{C}_{\mathrm{BM}}($ Stacks $\left.)\right)$

Grassroots cost $\mathrm{C}_{\mathrm{GR}}=\mathrm{C}_{\mathrm{TM}}+0.5 \mathrm{C}_{\mathrm{BM}}$

Data: $A_{\text {cell }}=200 \mathrm{~cm}^{2}, C_{\mathrm{fc}, \text { spec }}=0.1442 \$ / \mathrm{cm}^{2}, \mathrm{~N}_{\text {cell, } \max }=100, C_{\mathrm{h}, \mathrm{spec}}=0.46425 \$ / \mathrm{cm}^{2}$

\section{SMR Costing: ( $\left.P_{S M R}, T_{S M R}, N_{T}, N_{C H 4}, X_{C H 4}\right)[3,4]$}

$\operatorname{CEPCI}(2001)=397, \mathrm{FCEPI}_{(1)}=600 / 397 \& \operatorname{CEPCI}(2002)=400, \mathrm{~F}_{\mathrm{CEPCI}(2)}=600 / 400$

$\mathrm{F}_{\mathrm{M}}: \mathrm{CS}=1$

If $\mathrm{P}=$ reactor pressure $<1$ barg then $\mathrm{F}_{\mathrm{p}}=1$

$\mathrm{B} 1=1.49, \mathrm{~B} 2=1.52$

$\mathrm{F}_{\mathrm{BM}}=\mathrm{B} 1+\mathrm{B} 2 \cdot \mathrm{F}_{\mathrm{M}} \cdot \mathrm{F}_{\mathrm{P}}$

$\mathrm{V}_{\mathrm{SMR}, \mathrm{Cat}}=\frac{\mathrm{e}^{\frac{\mathrm{E}_{\mathrm{A}}}{\mathrm{R} \cdot \mathrm{T}_{\mathrm{SMR}}}}}{\mathrm{k} \cdot \rho_{\mathrm{b}} \cdot \mathrm{P}_{\mathrm{SMR}}}\left[-\left(\mathrm{F}_{\text {Total }}+2 \cdot \mathrm{F}_{\mathrm{CH} 4}\right) \ln \left(1-\mathrm{X}_{\mathrm{CH} 4}\right)-2 \cdot \mathrm{F}_{\mathrm{CH} 4} \cdot \mathrm{X}_{\mathrm{CH} 4}\right]$

Purchase (bare module) cost of reactor $C_{B M, R}=F_{C E P C I(1)} \cdot \operatorname{Cost}_{S M R, r e f}\left(\frac{V_{S M R, \text { Cat }} \cdot F_{V}}{V_{S M R, \text { ref }}}\right)^{0.6} \cdot F_{B M}$

Purchase (bare module) cost of catalyst $\mathrm{C}_{\mathrm{BM}, \mathrm{C}}=\mathrm{F}_{\mathrm{CEPCI}(2)} \cdot \mathrm{V}_{\mathrm{SMR}, \mathrm{Cat}} \mathrm{Cost}_{\mathrm{Cat}}$

Total module cost $\mathrm{C}_{\mathrm{TM}}=1.18\left(\mathrm{C}_{\mathrm{BM}, \mathrm{C}}+\mathrm{C}_{\mathrm{BM}, \mathrm{C}}\right)$

Grassroots cost $\mathrm{C}_{\mathrm{GR}}=\mathrm{C}_{\mathrm{TM}}+0.5 \mathrm{C}_{\mathrm{BM}}$

Data: CostsMR, ref $=21936 \$, F v=1.36, V_{S M R, \text { ref }}=0.0167 \mathrm{~m}^{3}$

Catalyst $-\mathrm{Ni} / \mathrm{Al}_{2} \mathrm{O}_{3}$, Costcat $=100,000 \$ / \mathrm{m}^{3}, \mathrm{k}=277.8 \mathrm{kmol} /(\mathrm{kg} . \mathrm{s} . \mathrm{bar}), \rho_{b}=1200 \mathrm{~kg} / \mathrm{m}^{3}$,

$$
E_{A}=129,790 \mathrm{~J} / \mathrm{mol}, \mathrm{R}=8.314 \mathrm{~J} /(\mathrm{mol} . \mathrm{K})
$$

\section{Burner Costing ( $\mathrm{mg}_{\mathrm{g}}, \mathrm{PR}_{\mathrm{sMR}}, \mathrm{T}_{\text {Burner }}$ ) [5]}

CEPCI $1998=390, \mathrm{~F}_{\mathrm{CEPCl}}=600 / 390$

$c=25.6(\mathrm{~kg} / \mathrm{s})^{-0.7}, \mathrm{~m}_{\mathrm{g}, \text { Ref }}($ burner outlet $)=460 \mathrm{~kg} / \mathrm{s}$

Purchase (bare module) cost $\mathrm{C}_{\mathrm{BM}}=\mathrm{F}_{\mathrm{CEPCI}} \cdot \mathrm{C} \cdot \mathrm{m}_{\mathrm{g}, \operatorname{Ref}}\left[\frac{\mathrm{m}_{\mathrm{g}}}{\mathrm{m}_{\mathrm{g}, \mathrm{Ref}}}\right]^{0.7} \frac{\left[1+\mathrm{e}^{0.015\left(\mathrm{~T}_{\mathrm{Burner}}-1540\right)}\right]}{\mid 0.995-{ }^{\mathrm{Put}_{\text {Out }} / \mathrm{P}_{\text {In }} \mid}}$

Total module cost $\mathrm{C}_{\mathrm{TM}}=1.18 \mathrm{C}_{\mathrm{BM}}$

Grassroots cost $C_{G R}=C_{T M}+0.5 C_{B M}$ 


\section{B. Objective Functions Calculations}

Steps for the calculation of the annual profit.

1. Capital cost is calculated using cost equations for different equipment. Then, annualized capital cost is calculated as follows:

Annualized capital cost $=$ total capital cost of all equipment $\times$ annualization factor

2. Raw material cost is calculated as follows:

Raw material cost $=$ annual bio-gas consumption $\times$ bio-gas price + annual $\mathrm{O}_{2}$ consumption $\times \mathrm{O}_{2}$ price

3. Utility cost is calculated as follows:

Utility cost $=$ annual boiler duty $\times$ boiler heat price + annual cooling water duty $\times$ cooling water price

4. Revenue is calculated as follows:

Revenue $=$ annual electricity production $\times$ electricity selling price

5. Finally, profit is calculated as follows:

Annual profit $=$ Revenue - Annualized capital cost - Raw material cost - Utility cost $\quad$ [\$ /year]

\section{REFERENCES}

[1] Turton, R., Bailie, R. C., Whiting, W. B., Shaeiwitz, J. A., 2012, “Analysis, Synthesis and Design of Chemical Processes," 4th ed., Prentice Hall.

[2] Palazzi, F., Autissier, N., Maréchal, F., Favrat, D., 2007, “A Methodology for Thermo-Economic Modeling and Optimization of Solid Oxide Fuel Cell Systems," Applied Thermal Engineering, 27(16), pp. 2703-2712.

[3] Maréchal F., Palazzi F., Godat J. and Favrat D., 2004, "Thermo-Economic Modelling and Optimization of Fuel Cell Systems," Fuel Cells, 5(1), pp. 5-24.

[4] Myers, D. B., Ariff G. D., James B. D., Lettow J. S., Thomas C. E., Kuhn R. C., 2002, “Cost and performance comparison of stationary hydrogen fueling appliances," Task 2 Report.

[5] Pelster S., 1998, "Environomic Modeling and Optimization of Advanced Combined Cycle Cogeneration Power Plants Including $\mathrm{CO}_{2}$ Separation Options," EPFL Thesis, pp. 89-90. 